\title{
Cross-Reactive Binding Antidrug Antibody Measurement
}

National Cancer Institute

\section{Source}

National Cancer Institute. Cross-Reactive Binding Antidrug Antibody Measurement. NCI Thesaurus. Code C147275.

The determination of the cross-reactive binding antidrug antibody in a biological sample. 